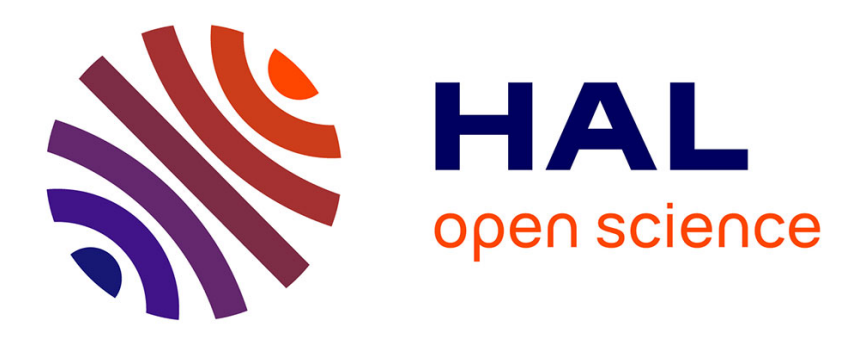

\title{
Mapping of low-temperature fatigue
}

O.B. Pedersen

\section{To cite this version:}

O.B. Pedersen. Mapping of low-temperature fatigue. Revue de Physique Appliquée, 1988, 23 (4), pp.690-690. 10.1051/rphysap:01988002304069000 . jpa-00245839

\section{HAL Id: jpa-00245839 https://hal.science/jpa-00245839}

Submitted on 1 Jan 1988

HAL is a multi-disciplinary open access archive for the deposit and dissemination of scientific research documents, whether they are published or not. The documents may come from teaching and research institutions in France or abroad, or from public or private research centers.
L'archive ouverte pluridisciplinaire HAL, est destinée au dépôt et à la diffusion de documents scientifiques de niveau recherche, publiés ou non, émanant des établissements d'enseignement et de recherche français ou étrangers, des laboratoires publics ou privés. 
MAPPING OF LOW-TEMPERATURE FATIGUE

O.B. Pedersen

Metallurgy Department

Ris $\varnothing$ National Laboratory

DK-4000 Roskilde, Denmark

Low-temperature single slip deformation of wellannealed fcc single crystals occurs in successive stages, as revealed for example by the shape of the tensile stress-strain curve. When a constant plastic strain is applied cyclically in push-pull the dislocation microstructure also builds up in successive stages. The stages of plastic flow, structural change and fracture can be summarised in a "fatigue diagram" of plastic strain amplitude e versus cycle number $N$. A fatigue diagram for $\mathrm{Cu}^{p a}$ single crystals strained in various single slip orientations was constructed (Fig. 1).

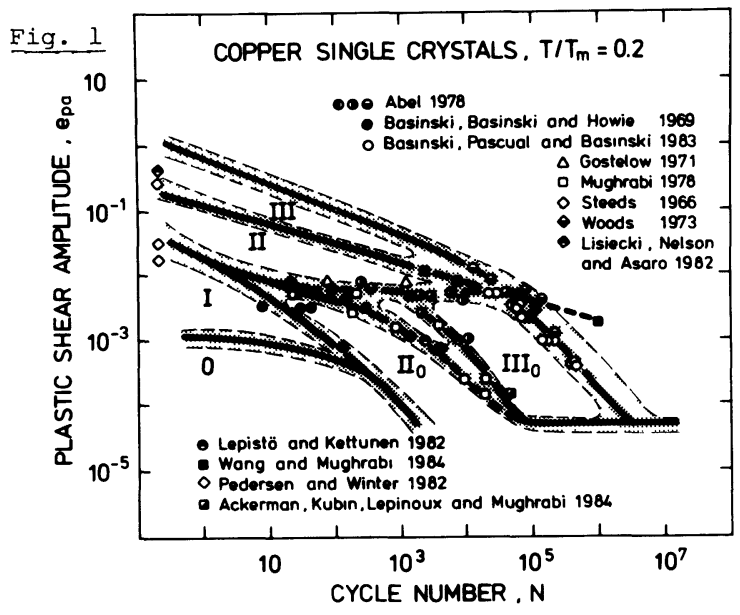

Flow and structural change in fields $0, I$, II and III are controlled by the dislocation mechanisms identified for the corresponding stages of tensile flow. Cycling into field II leads to formation and growth of clumps of primary edge dipoles (veins). The vein structure becomes unstable at the transition to field III, where persistent slip bands (PSBs) form. In field III a composite structure of PSBs in a matrix of veins has become established, and there is a competition between slow growth of short PSB cracks, inactivation of old PSBS and formation of new PSBs and short cracks. Observations for the "hard" symmetry orientations are, as yet, much less comprehensive; but it is clear that diagrams for hard orientations are quite different from those for the "soft" single slip orientations.

Fatigue diagrams for Al single crystals strained in single slip orientations were constructed for roomtemperature (and $77 \mathrm{~K}$ ) on the basis of limited data (Fig. 2). The diagrams appear to be qualitatively the same as the more complete diagram for $\mathrm{Cu}$ at room-temperature, in the sense that the same fields appear. The difference lies in the size and position of the fields. The existence of field III needs substantiation by electron microscopy. The dominance of field III disappears at lower temperatures.

The striking difference between the diagrams for $\mathrm{Cu}$ and $\mathrm{Al}$ is probably caused by cross-slip, rather than self-diffusion, the temperature being well below half the absolute melting temperature, $\mathrm{T}_{\mathrm{m}}$.

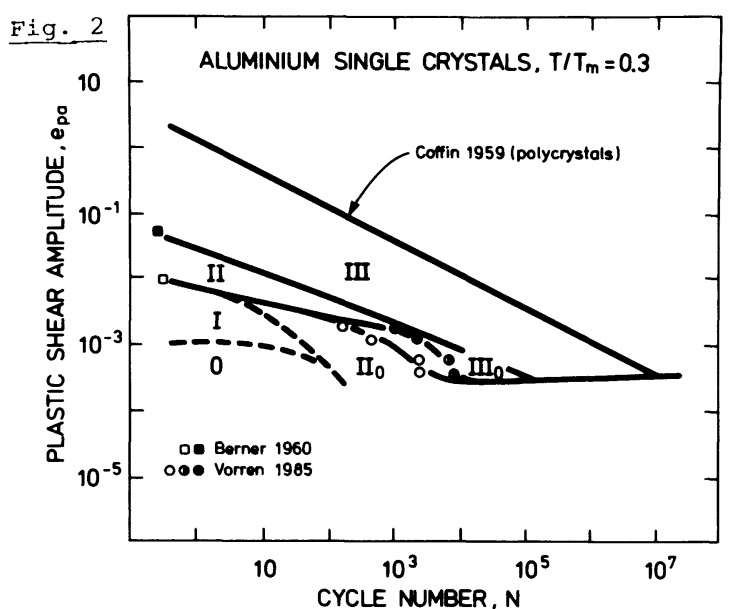

The body centred cubic metals display a transition from fully ductile to completely brittle fracture when the temperature is lowered and/or the strainrate increased. This is reflected in the fatigue diagram. High temperatures and low rates promote bcc fatigue diagrams similar to the fcc diagrams (say Al), but new fields appear in the transition temperature range. This is illustrated for Mo.

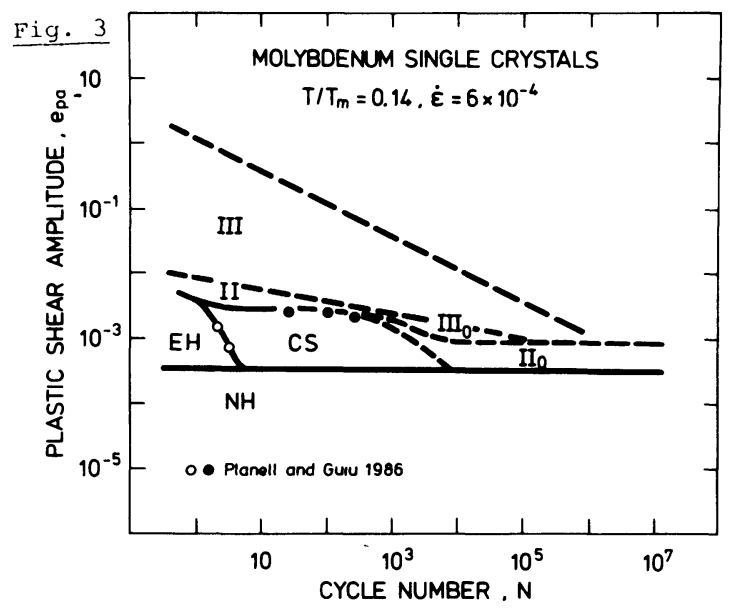

The limited mobility of bcc screw dislocations at $0.14 \mathrm{~T}_{\mathrm{m}}$ accounts for the appearance of fields $\mathrm{EH}$ ("exhaustion hardening") and CS ("cyclic softening"). In field NH ("no hardening") the strain amplitude is low enough to be carried by preexisting mobile edges, which glide to and fro without multiplication. Field III may not exist.

The dislocation core structure plays a crucial role but in most cases the field patterns in the diagrams remain empirical facts. A predictive theory of the instabilities causing the transition from one stage of structural evolution to the next does not exist. Yet, a detailed discussion of the theory, construction, limitations and possible applications of fatigue diagrams seems worthwhile. 